Research Article

\title{
Drinking water facility in urban field practice area of a medical college: a community based cross sectional study
}

\author{
Ashiq Rashid Mir*, Mahesh H. S., M. S. Rajanna, Krishna Iyengar, Cheluve Gowda
}

Department of Community medicine, Sri Siddhartha Medical College, SSAHE, Tumkur, India

Received: 23 June 2016

Accepted: 12 July 2016

\author{
*Correspondence: \\ Dr. Ashiq Rashid, \\ E-mail: leoashiq@gmail.com
}

Copyright: () the author(s), publisher and licensee Medip Academy. This is an open-access article distributed under the terms of the Creative Commons Attribution Non-Commercial License, which permits unrestricted non-commercial use, distribution, and reproduction in any medium, provided the original work is properly cited.

\begin{abstract}
Background: Rapid modernisation and fast urbanisation has led to rapid filling of urban areas and increased rise in migrant population in urban areas. Water is indispensible for survival of human beings thus providing safe drinking water is one of the most basic component of urban planning .1.8 Million people die of diarrhoea each year out of which majority are under 5 children and $88 \%$ of these under 5 deaths are due to unsafe drinking water (1). This study intends to assess the quality of drinking water.

Methods: A Cross sectional Study was conducted in Maralur and Maralur Dinne which are under the field practice area of Sri Siddhartha Medical College in Tumkur district of Karnataka.

Results: Municipal water supply was used by $79 \%$ of the people in the study. No treatment method was used for purification of water by $81 \%$ of households. $32 \%$ of people used earthen vessel to store water for drinking. $68 \%$ of people dipped glass in vessel using hands to take water for drinking. $46 \%$ of people had no knowledge about any disease caused by impure drinking water. Only $55 \%$ of households cleaned their water storage vessels once a week.

Conclusions: Source of drinking water supply from municipality and wells were unfit for consumption. Storage methods of drinking water are conducive for growth of pathogens. Knowledge about various diseases caused by impure drinking water is also poor. Hence drinking water supply is a challenge in urban settings.
\end{abstract}

Keywords: Water quality, Treatment methods, Drinking water

\section{INTRODUCTION}

In years to come, water, the need of life, is possibly to pose greatest challenge on account of its increased demand with population rise, economic development, and shrinking supplies due to rapid migration to urban areas and increased levels of pollution associated with it. ${ }^{1}$ Poor water quality continues to pose a major threat to human health (WHO 2014). Globally, about 4 billion cases of diarrhoea occur and about 1.8 million people die per year; the vast majority being children under 5 years of age, of which $88 \%$ is attributable to unsafe water. WHO estimates that $94 \%$ of diarrhoeal cases are preventable through interventions to increase the availability of clean water, and to improve sanitation and hygiene. ${ }^{2}$
Large numbers of households in cities around the developing world do not have access to one of the most basic of human needs - a safe and reliable supply of drinking water. In common with many developing countries, the fastest growing un-served populations live in urban and peri-urban areas. ${ }^{3}$

The quality of drinking-water is a powerful environmental determinant of health. Drinking-water quality management has been a key pillar of primary prevention for over one-and-a-half centuries and it continues to be the foundation for the prevention and control of waterborne diseases. 
There are several variants of the faecal-oral pathway of water-borne disease transmission. These include contamination of drinking-water catchments (e.g. by human or animal faeces), water within the distribution system (e.g. through leaky pipes or obsolete infrastructure) or of stored household water as a result of unhygienic handling. ${ }^{4}$

With the millennium development goal target 7 calls for reduction in the proportion of people without sustainable access to safe drinking-water and basic sanitation by 2015. Reaching this target implies, tackling access, scarcity and safety dimensions of drinking-water provision. ${ }^{4}$ Hence this study was undertaken with objectives to determine quality of drinking water at Municipal source and treatment methods for purification of water at household level.

\section{METHODS}

Tumkur is fast developing city in Karnataka state and is about $70 \mathrm{kms}$ from state capital, a metropolitan city Bangalore. Marralur and Marralur dinne are urban field practice areas under Sri Siddhartha Medic al college (SSMC) which has dwelling of 4250 houses. A cross sectional study was under taken between July and September 2015. The sample size of 220 households using prevalence of treatment methods from previous studies and systematic random sampling method was used to collect data. A written consent was taken from the respondents willing to participate in the study. Information was collected regarding the socio economic status of households, drinking water sources, treatment methodology and storage practices by completing a pretested questionnaire by interview and observational technique. Water samples from municipal water treatment plant (source of water supply to the city), tap water points in the area, bore wells and packed drinking water bottles were collected on 3 different days following WHO guidelines for water sample collection and were analysed at district surveillance office, Tumkur for bacteriology, fluorine level and residual chlorine. The collected data was entered in excel sheet and analysed using Epi Info version 3.5.3.

\section{RESULTS}

Among the households interviewed in this study, majority of the residents were Muslims $(68.6 \%)$, followed by Hindus $(38.4 \%)$. Among households nuclear families were $72.6 \%, 22.8 \%$ were joint families and $4.6 \%$ extended families. The socio economic grading of the households in the study area was as follows - Upper 2.7\%, Upper Middle 5\%, Lower middle 20\%, Upper lower $62.7 \%$ and Lower $9.5 \%$. (Table 1) The water sample from water treatment plant showed no residual chlorine making water supply highly prone to bacterial growth. 3 out of 5 water samples were found to be unsafe for drinking after analysis as there was high MNP and presence of faecal coliform count was also high .Bore well water sample has upper limit fluoride level (Table 2).

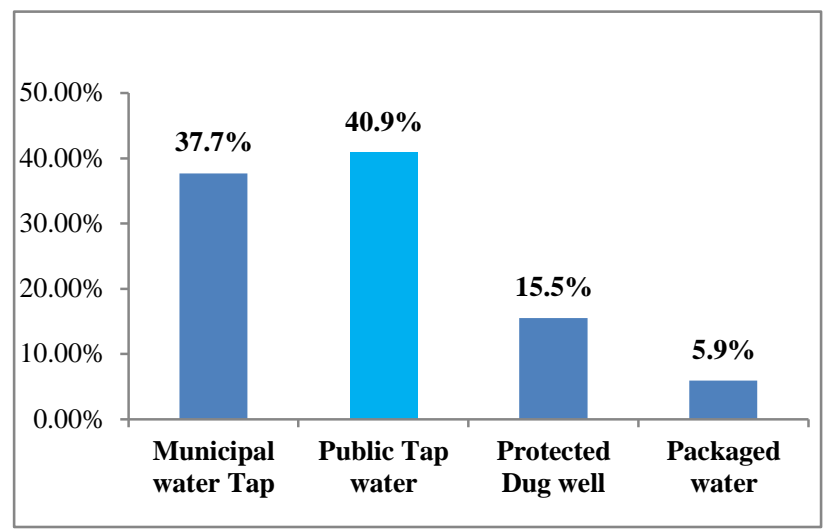

Figure 1: Source of drinking water.

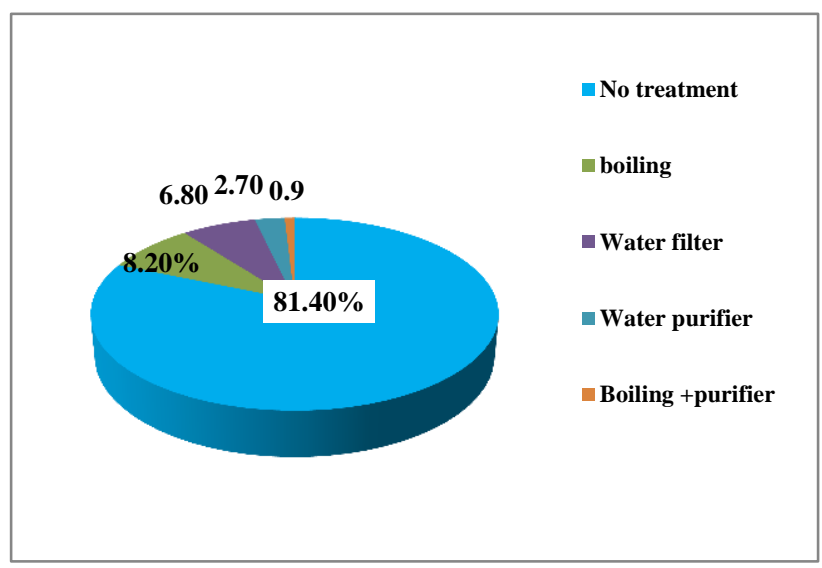

Figure 2: Water treatment methods at sample households.

Municipal public tap and municipal water connections were used by 40.9 and $37.7 \%$ of households $.15 .5 \%$ households used bore well water .Only $5.90 \%$ used packaged water for drinking which was considered Fit for consumption by water analysis (Table 2). $81.4 \%$ of households did not adopt any treatment method for purification of water. Boiling was practised by $8.2 \%$ of households. Only $6.80 \%$ used water filter method. $2.70 \%$ used water purifiers for treatment of drinking water at household level (Figure 1).

$32.3 \%$ households used earthen vessels for storage of water .Copper vessel was used by $28.60 \%$ of households. $20.90 \%$ of households used drums to store water while pure it was used by $5.50 \%$ of households (Figure 2). $67.7 \%$ of households used dipping of glass into the vessel using hands by each member. $16.40 \%$ used tap attached to storage vessel. $15.90 \%$ used storage vessel to pour water directly into the glass for drinking (Figure 3).

$55.5 \%$ of households are cleaning their storage vessels once a week. Storage vessels were daily cleaned by 22.3 $\%$ of household. $17.3 \%$ of households cleaned their 
storage vessels once in every 2 weeks while $4.5 \%$ of them cleaned on monthly basis (Figure 4).

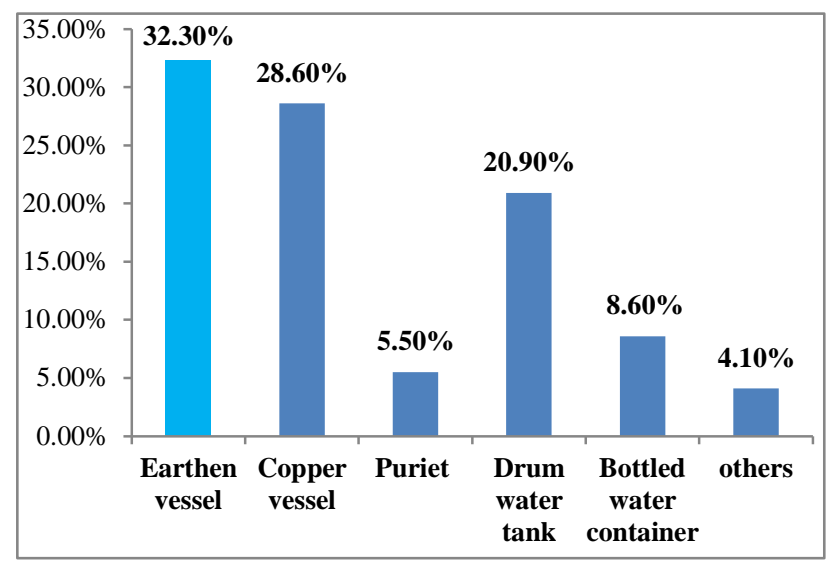

Figure 3: Storage vessels used among surveyed households.

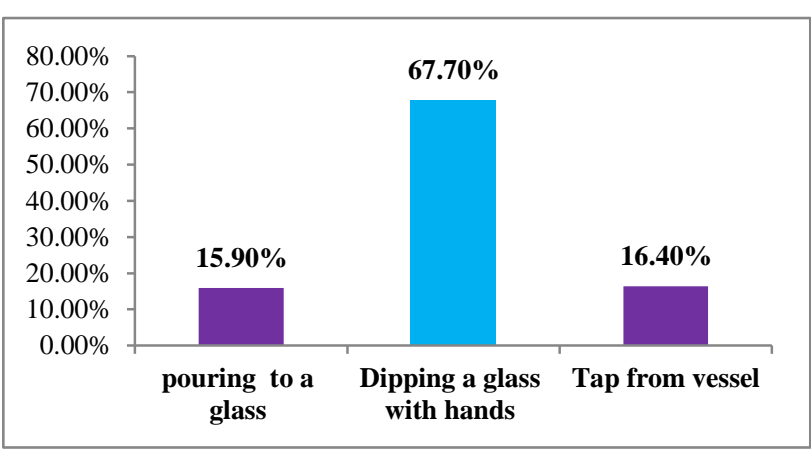

Figure 4: Practices of taking water from storage vessels for drinking purpose among households in Marallur and Marallur dinne.

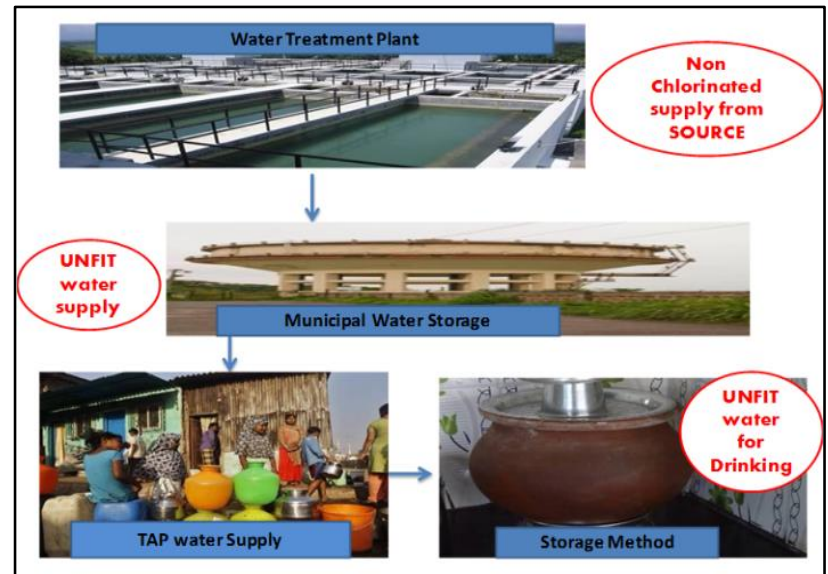

Figure 5: Summary.

Table 1: Socio- demographic characteristics of households.

\begin{tabular}{|lll|}
\hline Variable & Frequency & Percentage \\
\hline Religion & & \\
\hline Hindu & 69 & $38.4 \%$ \\
\hline Muslim & 161 & $68.6 \%$ \\
\hline Type of family & & \\
\hline Nuclear family & 159 & $72.6 \%$ \\
\hline Joint family & 50 & $22.8 \%$ \\
\hline Extended & 10 & $4.6 \%$ \\
\hline Socio-economic status & & \\
\hline Upper lower & 06 & $62.7 \%$ \\
\hline Lower middle & 11 & $20 \%$ \\
\hline Lower & 44 & $9.5 \%$ \\
\hline Upper middle & 138 & $5 \%$ \\
\hline Upper & 21 & $2.7 \%$ \\
\hline
\end{tabular}

Table 2: Water sample analysis for bacteriological testing and fluoride levels at district health laboratory, Tumkur.

\begin{tabular}{|c|c|c|c|c|c|}
\hline Water source & $\begin{array}{l}\text { MPN (Per } \\
100 \mathrm{ml})\end{array}$ & $\begin{array}{l}\text { F.Coliform count }{ }^{\#} \\
(\text { per } 100 \mathrm{ml})\end{array}$ & $\begin{array}{l}\text { Presence of } \\
\text { E.Coli }\end{array}$ & $\begin{array}{l}\text { Fluorine level } \\
\text { (Parts per million) }\end{array}$ & Result \\
\hline $\begin{array}{l}\text { Water treatment plant, } \\
\text { Tumkur }\end{array}$ & Nil & Nil & Negative & 0.14 & Non-chlorinated \\
\hline Tap water (Maralur) & 170 & 25 & Negative & 0.42 & Unfit \\
\hline $\begin{array}{l}\text { Tap water (Maralur } \\
\text { dine) }\end{array}$ & 110 & 25 & Negative & 0.15 & Unfit \\
\hline Bore well water & 140 & 17 & Negative & 1.1 & Unfit \\
\hline Package water & Nil & Nil & Nil & 0.44 & Fit \\
\hline
\end{tabular}

*MPN: Most Probable Number of bacteria, \# F.Coliform: Thermo-tolerant coliform.

\section{DISCUSSION}

The WHO guidelines suggest that E. coli (the indicator organism for bacterial contamination) should not be detectable in a 100-ml sample of water. Water-borne diseases from faecal contamination are one of the biggest public health risks in the country. Water monitoring conducted in January- March 2003 by Clean India in 28 cities found that ground water in most areas exceeded permissible limits in terms of fluoride, ammonia and hardness. Municipal water supply in some cities also contained high numbers of contaminants. A 2003 survey 
of 1000 locations in Kolkata found that $87 \%$ of water reservoirs serving residential buildings and $63 \%$ of taps had high levels of faecal contamination which are similar to our study. ${ }^{5}$

The National Family Health Survey-3/NFHS-3 showed that $88 \%$ of the population of India had access to an improved water source. Household survey conducted by Abdul Shaban et al in 2008 showed that a majority of households, as high as 92\%, in major cities in India depended on the municipal water supply for their daily needs. $^{10}$ Of this $92 \%$ of the population, $9.5 \%$ were dependent on community taps (1). Similarly, the study showed that about $83 \%$ of the houses in Boloor had their main source of drinking water as the municipality water supply. ${ }^{2}$ Our study also showed about $79 \%$ of households used municipal water supply for drinking. The study done by JMP (Joint monitoring Programme WHO) showed that $67 \%$ of the households surveyed in India did not follow any water treatment practices while $9 \%$ of the households boiled the water, and only $17 \%$ strained the water through the cloth. ${ }^{6}$ National Family Health Survey3/NFHS-3 showed that $45 \%$ of the people in Karnataka state did not treat drinking water prior to consumption. Our study found that $81 \%$ of the population did not use any method to treat water in their households. The results are much higher than the national and state values which are highly commendable. The lack of free Chlorine in the sample from water treatment plant and bore wells and dug wells of households studied in our study, points towards the chances of future contamination of the drinking water. This could be an alarm for the authorities to ensure the presence of residual chlorine. The source itself is inefficient to provide safe and healthy water supply to the houses in an urban area. This is worrying as the treatment practices and storage practices of drinking water are also facilitating contamination of drinking water. Water of good drinking quality is of basic importance to human physiology and man's continued existence depends very much on its availability. ${ }^{7}$ Drinking-water quality management has been a key pillar of primary prevention for over one-and-a-half centuries and it continues to be the foundation for the prevention and control of waterborne diseases. ${ }^{8}$

\section{CONCLUSION}

Source of water from municipal water supply had no residual chlorine making it vulnerable for future contamination. Tap and bore well water showed high counts of MPN and faecal coliform, making the drinking water supply extremely dangerous for consumption. Unsafe storage methods and no treatment of drinking water at household level is making drinking water dangerous for consumption.

\section{ACKNOWLEDGEMENTS}

Authors would like to thanks District health Office, Tumkur district, India.

Funding: No funding sources

Conflict of interest: None declared

Ethical approval: Institutional review board, SSAHE, Tumkur, India

\section{REFERENCES}

1. Abdul S. Water poverty in urban India: A study of major cities. Seminar paper. Jamia Millia Islamia central University. 2008. Available at: http://jmi.ac.in/upload/publication/Water_Poverty_i n_urban_India.pdf. Accessed on 26 June 2015.

2. Prasanna M. Drinking water in an urban area in South India: a community based cross sectional study. Australasian Medical Journal AMJ. 2010;3(5):295-8.

3. Isha R. Urban water supply in India: status, reform options and possible lessons. Water policy. Available at: http://www.mumbaidp24seven.in/reference/McKenz ieRay_India_urbanwater_forWP.pdf. Accessed on 15 June 2015.

4. World Health Organization. Water for Health WHO Guidelines for Drinking water Quality. 2010. Available at: http://www.who.int/water_sanitation_health/dwq/gu idelines/en/. Accessed on 15 May 2015.

5. Warning over Calcutta water quality. BBC News UK edition, 29 August, 2003.

6. World Health Organization /UNICEF. Joint Monitoring Programme (JMP) for water supply and sanitation. 2015. Available at: http://www.who.int/water_sanitation_health/monitor ing/en/. Accessed on 15 June 2015.

7. Ashvin G. An evaluation of physico-chemical parameters to assess borewell water quality from madyal and vadgaon villages of kagal Tahsil, MS, India. Int Res J Environment Sci. 2013;2(5):95-7.

8. Water For Health. WHO Guidelines for Drinkingwater. Quality 2010. Availible at :www.who.int/water_sanitation_health/dwq/gdwq3r ev. Accessed on June 192015.

Cite this article as: Mir RA, Mahesh HS, Rajanna MS, Iyangar K, Gowda C. Drinking water facility in urban field practice area of a medical college: a community based cross sectional study. Int $\mathrm{J}$ Community Med Public Health 2016;3:2287-90. 